\title{
14: $22658314-22656355$
}

National Cancer Institute

\section{Source}

National Cancer Institute. 14:22658314-22656355. NCI Thesaurus. Code C41951.

Physical location of CEBPE_Gene 